\title{
Early diagnosis of AKI in the ICU: urinary chitinase 3-like protein 1 as a novel renal troponin
}

\author{
J De Loor ${ }^{1 *}$, L De Crop ${ }^{2}$, C Clauwaert ${ }^{2}$, S Bracke ${ }^{2}$, D Vermeiren ${ }^{2}$, K Demeyere $^{1}$, E Meyer $^{1 \dagger}$, E Hoste $^{2 \dagger}$ \\ From ESICM LIVES 2015 \\ Berlin, Germany. 3-7 October 2015
}

\section{Introduction}

Our group recently validated urinary chitinase 3 -like protein 1 (UCHI3L1) as novel biomarker for acute kidney injury (AKI) in septic mice [1].

\section{Objectives}

This ensuing study aimed to investigate whether our preclinical finding could be translated to humans and whether UCHI3L1 performed equally to the AKI biomarker urinary neutrophil gelatinase-associated lipocalin (UNGAL) [2].

\section{Methods}

Prospective cohort study at the surgical and medical ICUs of the University Hospital Ghent from Sept. 2012 till Aug. 2014. Patients were included if: age $\geq 18$ y; arterial and urinary catheter present; expected ICU stay $\geq 48 \mathrm{~h}$; and respiratory or cardiovascular SOFA score $\geq 2$ resp. $\geq 1$. Participation was excluded if: AKI KDIGO Full stage $\geq 2$ at inclusion; chronic kidney disease stage 5 ; or no written informed consent.

Blood and urine were collected at inclusion. Each patient was sampled a $2^{\text {nd }}$ time at $6 \mathrm{pm}$ if the $1^{\text {st }}$ collection was before noon, then at 6 am and pm on days $2-4$, and at 6 am on days 5-7. The study stopped if the patient was discharged from the ICU before day 7 . Reference serum creatinine $(\mathrm{SCr})$ was defined as the lowest $\mathrm{SCr}$ value within the last 3 months prior to enrollment.

The primary endpoint was AKI KDIGO Full stage $\geq 2$ within $\mathbf{1 2} \mathbf{~ h}$ after enrollment. Secondary endpoints were: AKI KDIGO $_{\text {Full }}$ stage $\geq 2$ within $24 \mathrm{~h}$ and $7 \mathrm{~d}$ after

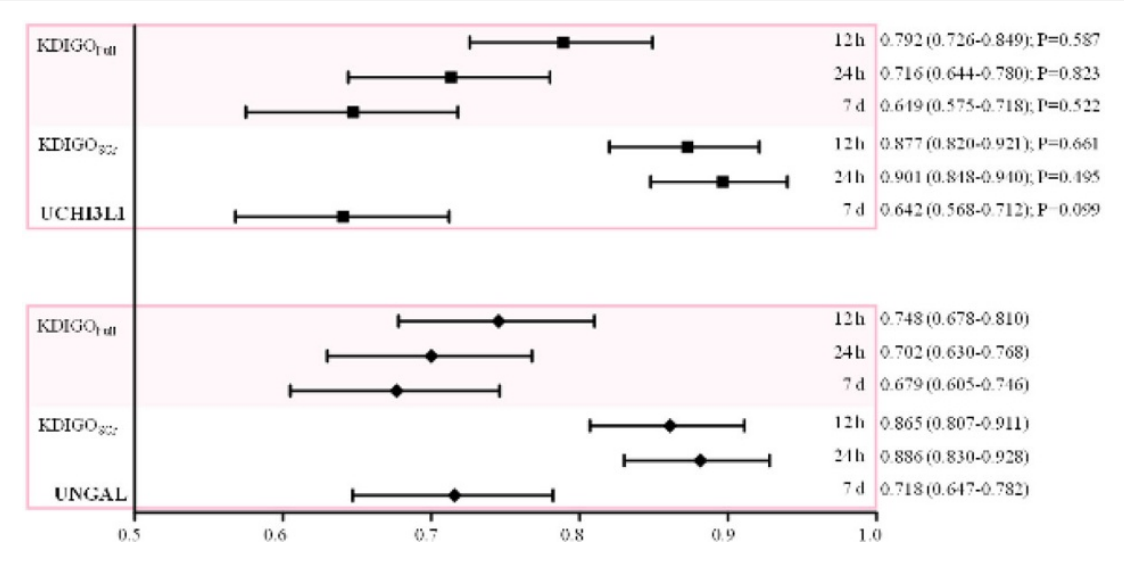

Figure 1

\footnotetext{
+ Contributed equally

'Ghent University, Laboratory of Biochemistry, Department of Pharmacology, Toxicology and Biochemistry, Faculty of Veterinary Medicine, Merelbeke,

Belgium

Full list of author information is available at the end of the article
}

(c) 2015 De Loor et al.; This is an Open Access article distributed under the terms of the Creative Commons Attribution License (http:// creativecommons.org/licenses/by/4.0), which permits unrestricted use, distribution, and reproduction in any medium, provided the original work is properly cited. 
enrollment; and AKI KDIGO ${ }_{\mathrm{SCr}}$ stage $\geq 2$ within $12 \mathrm{~h}, 24$ $\mathrm{h}$ and $7 \mathrm{~d}$ after enrollment.

\section{Results}

In total 181 patients were included, of which $6(3 \%)$ reached the primary endpoint. Baseline characteristics showed no differences with the exception of age $(70.5 \mathrm{y}$ [IQR: 65.8-78.0] vs. 59.0 [50.0-70.0] for endpoint pos. resp. neg.; $\mathrm{P}=0.040$ ). At ICU admission, the only significant difference was the proportion of patients referred from another department (66.7 vs. $22.3 \%$ for endpoint pos. resp. neg.; $\mathrm{P}=0.029$ ).

Both UCHI3L1 and UNGAL measured at inclusion were good predictors of the primary endpoint, with an AUC-ROC of 0.792 (95\% CI: 0.726-0.849) resp. 0.748 (0.678-0.810). The difference between both areas was not significant $(\mathrm{P}=0.587)$. Results for all endpoints are shown in Figure 1.

\section{Conclusions}

UCHI3L1 was a valuable diagnostic biomarker for moderate or severe AKI in this adult ICU cohort, and performed similar to UNGAL.

\section{Grant Acknowledgment}

FWO grant to De Loor J. IOF grant to Meyer E. and Hoste E.

Patent: US2014006991 and EP201211163. Valorisation: bimetra@uzgent.be.

\section{Authors' details}

'Ghent University, Laboratory of Biochemistry, Department of Pharmacology, Toxicology and Biochemistry, Faculty of Veterinary Medicine, Merelbeke, Belgium. ${ }^{2}$ Ghent University, ICU, Ghent University Hospital, Faculty of Medicine and Health Sciences, Ghent, Belgium.

Published: 1 October 2015

\section{References}

1. Mol Cell Proteomics 2012, 11:1-13.

2. Ann Clin Biochem 2014, 51:335-351.

doi:10.1186/2197-425X-3-S1-A840

Cite this article as: De Loor et al.: Early diagnosis of AKI in the ICU:

urinary chitinase 3 -like protein 1 as a novel renal troponin. Intensive Care

Medicine Experimental 2015 3(Suppl 1):A840.

\section{Submit your manuscript to a SpringerOpen ${ }^{\circ}$ journal and benefit from:}

- Convenient online submission

- Rigorous peer review

- Immediate publication on acceptance

- Open access: articles freely available online

- High visibility within the field

- Retaining the copyright to your article

Submit your next manuscript at $\gg$ springeropen.com 